\title{
Effects of pH and Ca competition on complexation of cadmium by fulvic acids and by natural organic ligands from a river and a lake
}

\author{
Jun Cao $\cdot$ Hanbin Xue $\cdot$ Laura Sigg
}

Received: 27 April 2006/Accepted: 27 August 2006/

Published online: 6 October 2006

(C) Springer Science+Business Media B.V. 2006

\begin{abstract}
The technique of competitive ligand-exchange/anodic stripping voltammetry (CLE-SV) was used to investigate effects of $\mathrm{pH}$ and $\mathrm{Ca}$ concentration on cadmium complexation by fulvic acid (FA), as well as Cd speciation in two different freshwaters, a hardwater Lake Greifen and a softwater River Wyre. Binding of Cd to Suwannee river FA $(10 \mathrm{mg} / \mathrm{l})$ was determined at different $\mathrm{pH}(7-8.5)$ and in the presence of various concentration of $\mathrm{Ca}^{2+}(0-2 \mathrm{mmol} / \mathrm{l})$. The results from one-ligand discrete models were compared to simulations by the WHAM VI model. In Lake Greifen, the determined dissolved $\left[\mathrm{Cd}^{2+}\right]$ ranged from $10^{-13}$ to $10^{-12} \mathrm{~mol} / \mathrm{l}$, and the conditional stability constant with natural ligands was $\log K_{\mathrm{CdL}}$ about 9.5-10.5 ( $\mathrm{pH}$ 8.6-8.8) with ligand concentrations of 1.2-7.8 $\times 10^{-6} \mathrm{~mol} / \mathrm{g} \mathrm{C}$. In the softwater River Wyre, dissolved $\left[\mathrm{Cd}^{2+}\right]$ ranged from $4 \times 10^{-12}$ to $1 \times 10^{-11} \mathrm{~mol} / \mathrm{l}$, and the ligands were weaker $\left(\log K_{\mathrm{CdL}}\right.$ 8.9-9.8, $\left.\mathrm{pH} 8.0\right)$ with lower ligand concentrations $\left(0.9-2.3 \times 10^{-6} \mathrm{~mol} / \mathrm{g} \mathrm{C}\right)$. The titration curves of FA samples were close to the simulated curves by the WHAM VI model at $\mathrm{pH} 8.0-8.5$, but deviated more from the model at lower $\mathrm{pH}$, indicating that the results determined with CLE-SV for CdFA complexation are relevant to the data base in the model. Calculation of the $\mathrm{Ca}$ competition for $\mathrm{Cd}$ binding by FA showed a competition effect of similar strength as the measured one, but indicated a systematic difference between measured and modeled data at $\mathrm{pH}$ 7.5. Using the WHAM model for comparison with FA, the complexation of $\mathrm{Cd}$ by the River Wyre ligands was close to that of FA, whereas stronger complexation was observed in the Lake Greifen water. These differences may originate from different ligand composition in the lake and the river.
\end{abstract}

Keywords FA complexation $\cdot \mathrm{pH} \cdot$ Calcium $\cdot \mathrm{Cd}$ speciation

J. Cao $\cdot$ H. Xue $(\varangle) \cdot$ L. Sigg

Eawag, Swiss Federal Institute of Aquatic Science and Technology, P.O. Box 611, CH-8600 Dübendorf, Switzerland

e-mail: xue@eawag.ch

J. Cao

Department of Urban \& Environmental Science, Laboratory of Earth surface process, Peking University, Beijing 100871, China 


\section{Introduction}

Cadmium, a non-essential element (with exception of its role in some marine algal species), may exert toxic effects to aquatic organisms when present at elevated concentrations in natural waters. Speciation of cadmium strongly influences its effects on aquatic organisms (Campbell et al. 2002; Kola and Wilkinson 2005; Toepperwien 2006; Vigneault and Campbell 2005). Studies on uptake of Cd by algae have indicated that $\mathrm{Cd}$ in many cases behaves according to the free ion activity model (Kola and Wilkinson 2005; Toepperwien 2006; Vigneault and Campbell 2005). It is thus of high interest to investigate the binding of cadmium by natural ligands, which may include dissolved, colloidal, and particulate ligands.

Cadmium will be mostly complexed by natural organic matter under natural water conditions. Binding of trace metals by natural organic ligands depends on the content of dissolved organic carbon (DOC), on its properties, on $\mathrm{pH}$, the competition by alkaline metals and the competition between various trace metals (Benedetti et al. 1995; Kinniburgh et al. 1996, 1999; Tipping 1993, 1998; Tipping and Hurley 1992). Binding of $\mathrm{Cd}$ with various natural organic ligands from river, lake, compost, and soil solution has been examined (Abate and Masini 2002; Kaschl et al. 2002; Kinniburgh et al. 1996, 1999; Otto et al. 2001; Xue and Sigg 1998, 1999).

Humic substances occur ubiquitously in water systems and may play an important role for trace metal speciation. They have been extensively studied with respect to their binding properties for trace metals and major ions (Kinniburgh et al. 1996; Tipping 1998; Tipping and Hurley 1992). Several models describing the binding properties of humic and fulvic acids (FA) with a range of metals are available (Gustafsson 2001; Kinniburgh et al. 1996; Tipping 1998; Tipping and Hurley 1992). However, only few studies have compared binding of metals by isolated fulvic and humic acids (HA) with complexation by unfractionated natural water samples using the same analytical methods (Xue and Sigg 1999). Similarly, the models for metal complexation with fulvic and humic acids have been only in few cases confronted with actual speciation measurements in natural waters (Meylan et al. 2004; Unsworth et al. 2006).

In rivers and lakes, major ion concentrations and $\mathrm{pH}$ vary widely. Binding of $\mathrm{Cd}$ by HA and FA and by other organic ligands are likely to be affected by major ions, especially $\mathrm{Ca}^{2+}$ ions, and by proton competition. To compare the complexation of $\mathrm{Cd}$ by natural organic ligands in various types of natural freshwaters, in particular if including hardwaters and softwaters, the effect of $\mathrm{Ca}$ and $\mathrm{pH}$ have to be considered. Natural organic ligands from different sources may be heterogeneous with respect to molecular weight and content of reactive functional groups, and thus with respect to their metal binding properties. To better compare complexation by FA and by natural organic ligands in natural waters of different major ion composition and $\mathrm{pH}$, we examine here the effects of $\mathrm{Ca}^{2+}$ ions and of protons on binding of $\mathrm{Cd}^{2+}$ by FA.

Numerous analysis techniques are applied in metal speciation studies (Sigg et al. 2006; Van Leeuwen et al. 2005). Here we use competitive ligand exchange/anodic stripping voltammetry (CLE-SV), which has adequate sensitivity and allows metalto-ligand ratios to be easily varied over a relatively wide range (Xue and Sigg 1998, 2002). Titrations of ligands (FA and ligands in natural water samples) are interpreted with respect to conditional stabilility constants and ligand concentrations using the program FITEQL (Westall 1982). 
In this study, the effects of $\mathrm{pH}$ and $\mathrm{Ca}^{2+}$ on $\mathrm{Cd}$ complexation by Suwannee river fulvic acid (SRFA) are investigated. These results are compared to the complexation of $\mathrm{Cd}$ by natural organic ligands from two sampling sites, namely River Wyre, a softwater site, and Lake Greifen, a hardwater site. The results were evaluated with the help of modeling, using the WHAM VI model for binding of Cd by FA (Tipping 1998).

\section{Experimental part}

\subsection{CLE-SV for cadmium complexation}

The method to determine the Cd complexation by natural organic ligands is based on competitive ligand exchange using ethylenediamine (EN) and differential pulse anodic stripping voltammetry measurement (CLE-SV), details of which are described elsewhere (Xue and Sigg 1998, 2002). The samples are titrated with Cd in the presence of excess EN. The added EN competes with the natural organic ligands in the sample to increase the concentration of labile complexes and therefore improves the measurement sensitivity. In the presence of an excess of EN, the CdEN complexes are the predominant labile organic complexes. Therefore, the free $\mathrm{Cd}$ ion concentration $\left[\mathrm{Cd}^{2+}\right]$ can be calculated based on the equilibria with $\mathrm{CdEN}$. The labile $\mathrm{Cd}$ concentration is determined from the peak current $i_{\mathrm{p}}$ and DPASV sensitivity $S$, and its concentration includes free ions, inorganic ligand bound, and EN bound species. $\left[\mathrm{Cd}^{2+}\right]$ is then determined by Eq. 2:

$$
\begin{gathered}
{[\mathrm{Cd}]_{\mathrm{lab}}=i_{\mathrm{p}} / S=\left[\mathrm{Cd}^{2+}\right]+[\mathrm{Cd}]_{\mathrm{in}}+[\mathrm{Cd}]_{\mathrm{EN}}=\left[\mathrm{Cd}^{2+}\right] \times\left(1+\alpha_{\mathrm{in}}+\alpha_{\mathrm{EN}}\right)} \\
{\left[\mathrm{Cd}^{2+}\right]=[\mathrm{Cd}]_{\mathrm{lab}} /\left(1+\alpha_{\mathrm{in}}+\alpha_{\mathrm{EN}}\right)}
\end{gathered}
$$

The $[\mathrm{Cd}]_{\mathrm{lab}},\left[\mathrm{Cd}^{2+}\right],[\mathrm{Cd}]_{\mathrm{in}}$ and $[\mathrm{Cd}]_{\mathrm{EN}}$ represent the concentration of labile $\mathrm{Cd}$, free $\mathrm{Cd}$ ions, inorganic and EN complexes, respectively. The complexing coefficients of inorganic ligands and of $\mathrm{EN}\left(\alpha_{\text {in }}\right.$ and $\left.\alpha_{\mathrm{EN}}\right)$ are equal to the ratio of the concentration of the corresponding complexes to free $\mathrm{Cd}$ ions, as calculated from the major inorganic ion composition, $\mathrm{pH}$ and the added EN concentration (Xue and Sigg 1998).

The data set of $\left[\mathrm{Cd}^{2+}\right]$ and corresponding natural $\mathrm{Cd}$ concentration $(\mathrm{Cd}$ bound to natural inorganic and organic ligands) is fitted with a one ligand discrete model, using the program FITEQL (Westall 1982). In the model, Cd bound to the binding sites of natural organic ligands, L (omitting the charges for simplicity), can be written as:

$$
\begin{aligned}
& \mathrm{Cd}^{2+}+\mathrm{L}=\mathrm{CdL} \\
& K_{\mathrm{CdL}, \text { cond }}=\frac{[\mathrm{CdL}]}{\left[\mathrm{Cd}^{2+}\right]\left[\mathrm{L}_{\mathrm{f}}\right]}=\frac{[\mathrm{CdL}]}{\left[\mathrm{Cd}^{2+}\right]\left([\mathrm{L}]_{\text {avail }}-[\mathrm{CdL}]\right)}
\end{aligned}
$$

where $\left[\mathrm{L}_{\mathrm{f}}\right]$ and $[\mathrm{CdL}]$ are the concentrations of free (unbound) and bound ligand. The corresponding conditional stability constant at the determined conditions, $K_{\mathrm{CdL}}$ cond, 
and the available ligand total concentrations $[\mathrm{L}]_{\text {avail }}$ (the sum of $[\mathrm{CdL}]$ and $\left[\mathrm{L}_{\mathrm{f}}\right]$ ) are obtained from the chemical equilibrium program FITEQL (Westall 1982).

\subsection{Samples}

Suwannee river fulvic acid (Leenheer 1989) was purchased from the International Humic Substances Society.

The water samples were collected from River Wyre in England and Lake Greifen in Switzerland, as described in more detail by Sigg et al. (2006). pH value and temperature of samples were measured in situ. The samples for speciation measurements were filtered through $0.45 \mu \mathrm{m}$ cellulose nitrate filters (Sartorius) in the laboratories under laminar flow clean benches. The samples were kept in polyethylene bottles in the dark at $4^{\circ} \mathrm{C}$ until the speciation determination and were analyzed within 1 week. All sampling and treatment devices, bottles and filters were soaked in $0.01 \mathrm{~mol} / \mathrm{l}$ suprapure $\mathrm{HNO}_{3}$ for at least 3 days, then rinsed 4 5 times with nanopure water. Blank values for $\mathrm{Cd}$ were $<0.04 \mathrm{nM}$. Total dissolved trace metal concentrations were determined by ICP-MS (inductively coupled plasma-mass spectrometry, a Perkin-Elmer Elan 5000). Major ions and other analytical parameters were measured as described in Sigg et al. (2006).

\subsection{Titration experiments and analyses}

The effects of $\mathrm{pH}$ and calcium on Cd complexation were examined in FA solutions prepared from SRFA. The solutions prepared for titration contained $10 \mathrm{mg} / \mathrm{l} \mathrm{FA}$, $0.01 \mathrm{~mol} / \mathrm{KNO}_{3}$ and $2 \mathrm{mmol} / \mathrm{l}$ 3-Morpholinopropanesulfonic acid (MOPS) buffer adjusted to the appropriate $\mathrm{pH}$. The titration was done at $\mathrm{pH} 7,7.5,8$, and 8.5 when $1 \mathrm{mmol} / 1 \mathrm{CaCO}_{3}$ added, and in another series, 2, $1,0.5,0.1$, and $0 \mathrm{mmol} / 1 \mathrm{CaCO}$ were added, respectively, at constant $\mathrm{pH} 7.5 \mathrm{pH}$ was calibrated with buffers. Added $\mathrm{Cd}$ ranged from $1 \mathrm{nmol} / 1$ to $50 \mathrm{nmol} / 1$ for each titration series. At $\mathrm{pH} 8$ and 8.5 , $1 \mathrm{mmol} / \mathrm{l} \mathrm{EN}$ (adjusted to corresponding $\mathrm{pH}$ value with diluted $\mathrm{HNO}_{3}$ ) was added. At lower $\mathrm{pH}$ ( 7 and 7.5), there was no addition of EN because the weaker FA binding sites were mostly dissociated, therefore could be neglected in the speciation calculation and $\alpha_{\mathrm{EN}}$ would be too small to improve the determination.

Titration experiment of samples from softwater (River Wyre) and hardwater (Lake Greifen) were carried out at $\mathrm{pH}$ close to the natural values, buffered with $1 \mathrm{mM}$ MOPS adjusted to the appropriate $\mathrm{pH}$. The initial $\mathrm{pH}$ of samples from Greifen were 8.5-8.7, and the working $\mathrm{pH}$ was checked after determination. The ionic strength was kept constant with $0.01 \mathrm{~mol} / 1 \mathrm{KNO}_{3}$. The Cd titration ranged from $10 \mathrm{nmol} / 1$ to $120 \mathrm{nmol} / \mathrm{l}$ for samples from Wyre and $1.72 \mathrm{nmol} / \mathrm{l}$ to $23.5 \mathrm{nmol} / \mathrm{l}$ for samples from Greifen.

All the samples for titration were equilibrated overnight at room temperature $\left(21 \pm 1^{\circ} \mathrm{C}\right)$. No kinetic effects have been observed in the titration experiments after this equilibration time. Labile Cd was measured using a Metrohm 757 polarograph with a hanging mercury drop electrode and a $\mathrm{Ag} / \mathrm{AgCl}$ reference electrode. After $\mathrm{N}_{2}$ purging for $5 \mathrm{~min}$ (when the concentration of $\mathrm{CaCO}_{3}$ was 2 and $1 \mathrm{mmol} / \mathrm{l}$ at $\mathrm{pH} 7$ and 7.5, $\mathrm{N}_{2}+\mathrm{CO}_{2}$ was used instead of $\mathrm{N}_{2}$ to keep $\mathrm{pH}$ stable after purging), Cd was accumulated at the hanging mercury drop at $-1.1 \mathrm{~V}$ for 4 min with $2,000 \mathrm{rpm}$ stirring. Potential scanning starts after $15 \mathrm{~s}$ equilibration time, the stripping potential 
was from $-0.9 \mathrm{~V}$ to $-0.4 \mathrm{~V}$, the scan pulse height was $20 \mathrm{mV}$, the pulse time was $0.1 \mathrm{~s}$ (for samples from Wyre and FA) or $0.01 \mathrm{~s}$ (for samples from Greifen), the voltage step was $6 \mathrm{mV}$, the voltage step time was $0.4 \mathrm{~s}$ and the sweep rate was 0.015 $\mathrm{V} / \mathrm{s}$.

\section{Results}

\subsection{Influence of $\mathrm{Ca}^{2+}$ and $\mathrm{H}^{+}$competition on $\mathrm{Cd}$ complexation by FA}

The effect of calcium ions on the Cd-FA binding curves in terms of $\log \left[\mathrm{Cd}^{2+}\right]$ versus $\left[\mathrm{Cd}_{\text {natural }}\right]$ is shown in Fig. 1 , where $\left[\mathrm{Cd}_{\text {natural }}\right]$ is equal to total $\mathrm{Cd}$ in solution minus EN bound $\mathrm{Cd} .\left[\mathrm{Cd}^{2+}\right]$ in equilibrium with $\mathrm{FA}$ is increasing with increasing $\mathrm{Ca}$, indicating competition by $\mathrm{Ca}$ for the binding sites. The fitted complexation parameters are listed in Table 1. The fitted binding parameters do not show a clear dependence on the $\mathrm{Ca}$ concentration. Modeling of these results by the WHAM model is also shown in Fig. 1. A clear dependence of $\mathrm{Cd}^{2+}$ on $\mathrm{Ca}^{2+}$ is also obtained in the model, but the results are shifted in comparison to the experimental data.

The titrations of FA with $\mathrm{Cd}$ at different $\mathrm{pH}$ are shown in Fig. 2. With decreasing $\mathrm{pH}$, the $\mathrm{Cd}^{2+}$ concentration obviously increased at the same $\mathrm{Cd}_{\text {natural }}$ concentration, indicating competition by protons. The fitted conditional stability constant, log $K_{\mathrm{CdFA}}$, cond and the available binding site concentration, $\mathrm{L}_{\text {avail }}$, both increased with $\mathrm{pH}$. Modeling of these results by the WHAM model is also shown in Fig. 2. The WHAM model predicts less $\mathrm{pH}$-dependence of $\mathrm{Cd}^{2+}$ than experimentally observed.

\subsection{Binding parameters of samples from River Wyre and Lake Greifen}

The complexation curves of $\mathrm{Cd}$ with natural organic ligands in softwater (River Wyre) and hardwater (Lake Greifen) are plotted in Figs. 3 and 4 for samples taken at various times. Table 2 lists the resulting conditional stability constant, ligand

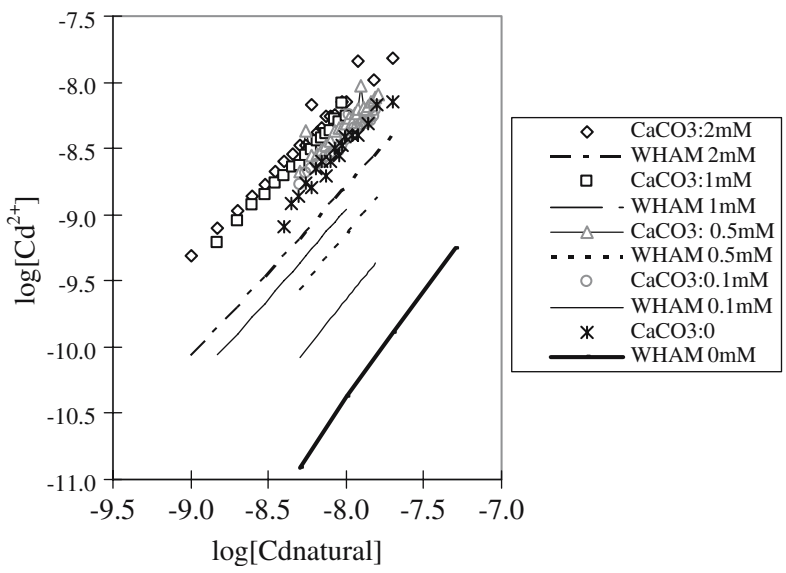

Fig. 1 Titration curves of fulvic acid $(10 \mathrm{mg} / \mathrm{l})$ with $\mathrm{Cd}$ in terms of $\log \left[\mathrm{Cd}^{2+}\right]$ versus $\log \left[\mathrm{Cd}_{\text {natural }}\right]$ at different $\left[\mathrm{Ca}^{2+}\right]$ concentration $(\mathrm{pH} 7.5)$. The symbols represent the titration data of various samples and the lines are computed by the WHAM model 
Table 1 Effect of calcium competition and $\mathrm{pH}$ on binding parameters of $\mathrm{Cd}$ with FA; $K_{\mathrm{CdFA}}$ is the calculated conditional stability constant for binding of Cd to FA, $\mathrm{L}_{\text {avail }}$ the concentration of available ligands

\begin{tabular}{lllll}
\hline$\left[\mathrm{Ca}^{2+}\right](\mathrm{mol} / \mathrm{l})$ & $\mathrm{pH}$ & $\log K_{\mathrm{CdFA}, \text { cond }}$ & $\mathrm{L}_{\text {avail }}(\mathrm{mol} / \mathrm{l})$ & $\mathrm{L}_{\text {avail }}(\mathrm{mol} / \mathrm{g} \mathrm{C})$ \\
\hline Calcium competition & & & & \\
0.002 & 7.5 & 8.40 & $4.14 \times 10^{-9}$ & $4.14 \times 10^{-7}$ \\
0.001 & 7.5 & 8.25 & $7.95 \times 10^{-9}$ & $7.95 \times 10^{-7}$ \\
0.0005 & 7.5 & 8.25 & $1.10 \times 10^{-8}$ & $1.10 \times 10^{-6}$ \\
0.0001 & 7.5 & 7.02 & $1.77 \times 10^{-7}$ & $1.77 \times 10^{-5}$ \\
0 & 7.5 & 8.01 & $2.56 \times 10^{-8}$ & $2.56 \times 10^{-6}$ \\
Proton competition & & & & \\
0.001 & 7.0 & 8.19 & $4.73 \times 10^{-9}$ & $4.73 \times 10^{-7}$ \\
0.001 & 7.5 & 8.25 & $7.95 \times 10^{-9}$ & $7.95 \times 10^{-7}$ \\
0.001 & 8.0 & 8.57 & $1.67 \times 10^{-8}$ & $1.67 \times 10^{-6}$ \\
0.001 & 8.5 & 9.07 & $1.70 \times 10^{-8}$ & $1.70 \times 10^{-6}$ \\
\hline
\end{tabular}

Fig. 2 Titration curves of fulvic acid $(10 \mathrm{mg} / \mathrm{l})$ with $\mathrm{Cd}$ in terms of $\log \left[\mathrm{Cd}^{2+}\right]$ versus $\log \left[\mathrm{Cd}_{\text {natural }}\right]$ at different $\mathrm{pH}$. The symbols represent the titration data of various samples and the lines are computed by the WHAM model

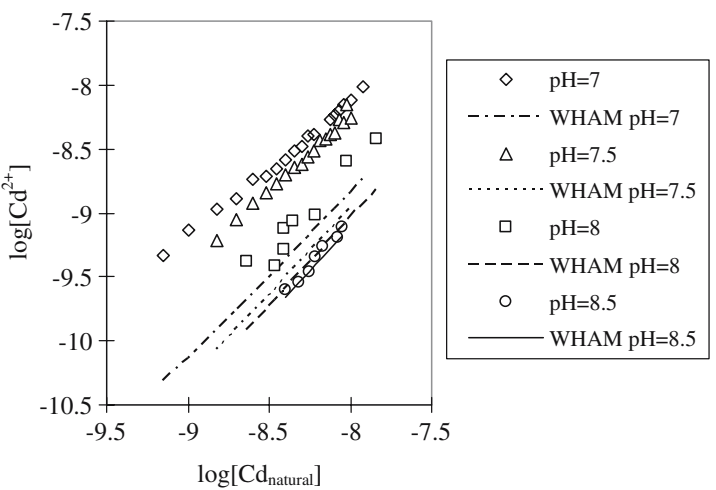

concentrations, working $\mathrm{pH}$, total $\mathrm{Cd}$ concentration, and ambient free $\mathrm{Cd}$ in the samples. The total dissolved Cd concentrations range from 0.083 to $0.186 \mathrm{nM}$, and free $\mathrm{Cd}^{2+}$ are from $4 \times 10^{-12}$ to $1 \times 10^{-11} \mathrm{M}$ in River Wyre. In Lake Greifen, the total $\mathrm{Cd}$ are from 0.018 to $0.116 \mathrm{nM}$, and free $\mathrm{Cd}^{2+}$ from $1 \times 10^{-13}$ to $1 \times 10^{-12} \mathrm{M}$. Free $\mathrm{Cd}^{2+}$ is thus much lower in Lake Greifen than in River Wyre. Only about $5 \%$ and $1 \%$ of $\mathrm{Cd}$ are calculated to be as free ion species in Wyre and Greifen, respectively. The conditional stability constant of samples from Greifen (9.5-10.5) are higher than those from River Wyre (8.9-9.8), at somewhat lower pH in River Wyre, and the ligand concentrations are also higher. The complexation of Cd by natural organic ligands in lake Greifen is thus stronger than that in River Wyre.

\section{Discussion}

\subsection{Competition of $\mathrm{Ca}^{2+}$ and $\mathrm{H}^{+}$with $\mathrm{Cd}^{2+}$ for binding sites of FA}

Competition of $\mathrm{Ca}^{2+}$ and $\mathrm{H}^{+}$with $\mathrm{Cd}^{2+}$ for binding sites of FA is evident from Figs. 1 and 2. Although the experimental data can be fitted with one-ligand models, more elaborate models are necessary to take into account both the effects of calcium ions 
Fig. 3 Titration curves of $\mathrm{Cd}$ with natural organic ligands from river Wyre $(\mathrm{pH}=8.0)$. The symbols represent the titration data of various samples (ambient concentrations with solid points); the lines are computed by one-ligand models using the parameters given in Table 2

Fig. 4 Titration curves of $\mathrm{Cd}$ with natural organic ligands from Lake Greifen $(\mathrm{pH}=8.6)$. The symbols represent the titration data of various samples (ambient concentrations with solid points); the lines are computed by one-ligand models using the parameters given in Table 2
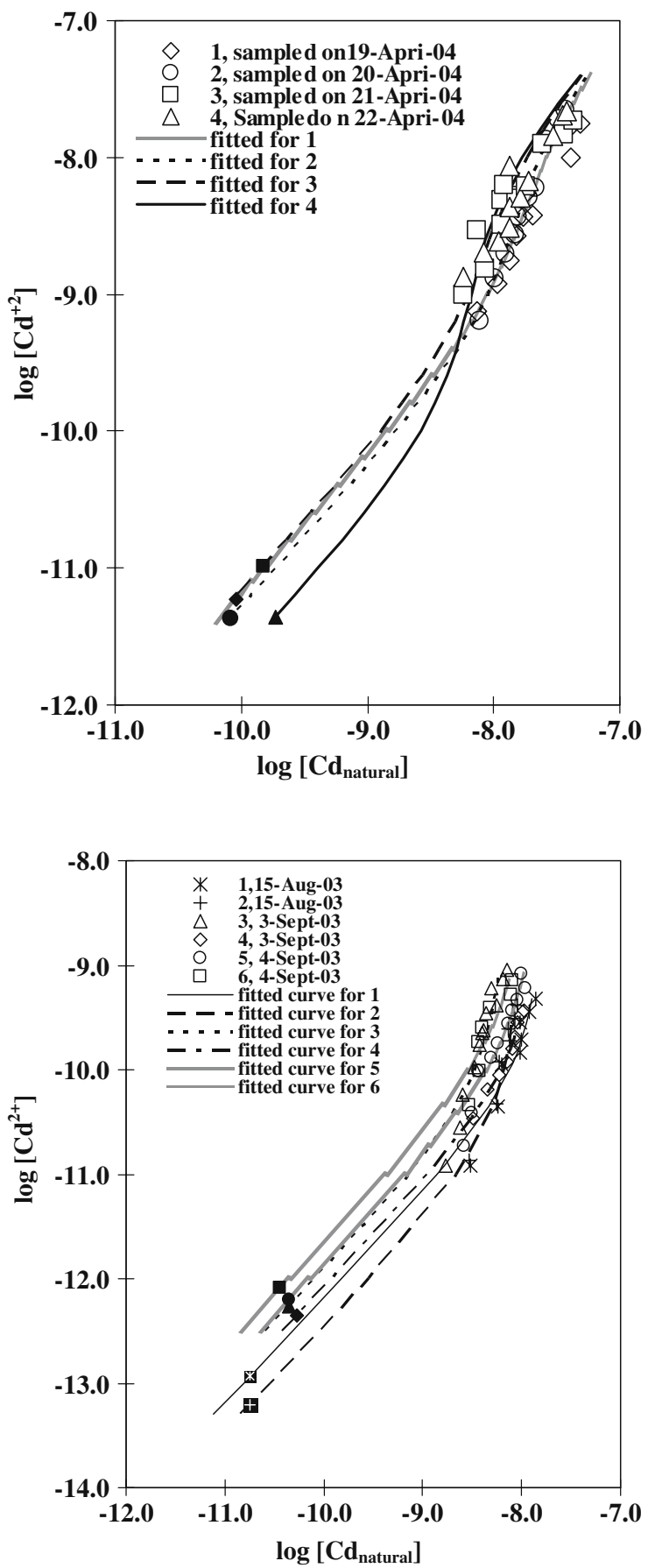

and protons. Using the WHAM model, the effects of $\mathrm{Ca}^{2+}$ and $\mathrm{H}^{+}$are simulated. The results on competition by $\mathrm{H}+$ shown in Fig. 2 indicate only a weak competition effect according to the WHAM model. The stronger $\mathrm{pH}$ effect, which was detected 
Table 2 Binding parameters of Cd with natural organic ligands from River Wyre and Lake Greifen; $K_{\mathrm{CdL}}$ is the calculated conditional stability constant for binding of $\mathrm{Cd}$ to natural organic ligands, $\mathrm{L}_{\text {avail }}$ the concentration of available ligands

\begin{tabular}{lllllll}
\hline & $\begin{array}{l}\text { Working } \\
\mathrm{pH}\end{array}$ & {$[\mathrm{Cd}]_{\text {total }} \mathrm{mol} / \mathrm{l}$} & $\begin{array}{l}\mathrm{log} \\
K_{\mathrm{CdL}, \text { cond }}\end{array}$ & $\begin{array}{l}\mathrm{L}_{\text {avail }} \\
\mathrm{mol} / \mathrm{l}\end{array}$ & $\begin{array}{l}\mathrm{L}_{\text {avail }} \\
\mathrm{mol} / \mathrm{g} \mathrm{C}\end{array}$ & $\begin{array}{l}{\left[\mathrm{Cd}^{2+}\right]_{\mathrm{amb}}} \\
\mathrm{mol} / \mathrm{l}\end{array}$ \\
\hline River Wyre & & & & & & \\
Sample 1 & 8.0 & $9.1 \times 10^{-11}$ & 8.9 & $1.79 \times 10^{-8}$ & $2.26 \times 10^{-6}$ & $6 \times 10^{-12}$ \\
Sample 2 & 8.0 & $8.3 \times 10^{-11}$ & 9.1 & $1.39 \times 10^{-8}$ & $1.40 \times 10^{-6}$ & $4 \times 10^{-12}$ \\
Sample 3 & 8.0 & $1.5 \times 10^{-10}$ & 9.2 & $8.30 \times 10^{-9}$ & $1.06 \times 10^{-6}$ & $1 \times 10^{-11}$ \\
Sample 4 & 8.0 & $1.9 \times 10^{-10}$ & 9.8 & $6.39 \times 10^{-9}$ & $9.10 \times 10^{-7}$ & $4 \times 10^{-12}$ \\
Lake Greifen & & & & & & \\
Sample 1 & 8.8 & $1.8 \times 10^{-11}$ & 10.0 & $1.47 \times 10^{-8}$ & $3.13 \times 10^{-6}$ & $1 \times 10^{-13}$ \\
Sample 2 & 8.6 & $4.4 \times 10^{-11}$ & 9.8 & $1.16 \times 10^{-8}$ & $2.27 \times 10^{-6}$ & $6 \times 10^{-13}$ \\
Sample 3 & 8.8 & $1.8 \times 10^{-11}$ & 10.5 & $8.53 \times 10^{-9}$ & $1.81 \times 10^{-6}$ & $1 \times 10^{-13}$ \\
Sample 4 & 8.6 & $4.4 \times 10^{-11}$ & 10.2 & $5.54 \times 10^{-9}$ & $1.20 \times 10^{-6}$ & $5 \times 10^{-13}$ \\
Sample 5 & 8.6 & $3.6 \times 10^{-11}$ & 9.7 & $8.63 \times 10^{-9}$ & $1.80 \times 10^{-6}$ & $8 \times 10^{-13}$ \\
Sample 6 & 8.6 & $1.2 \times 10^{-10}$ & 9.5 & $3.68 \times 10^{-8}$ & $7.83 \times 10^{-6}$ & $1 \times 10^{-12}$ \\
Sample 7 & 8.6 & $5.3 \times 10^{-11}$ & 10.0 & $1.30 \times 10^{-8}$ & $2.95 \times 10^{-6}$ & $4 \times 10^{-13}$ \\
\hline
\end{tabular}

using the CLE-SV method may be due to the inclusion of weaker labile FA species in the measurement by the SV method, in addition to $\mathrm{Cd}^{2+}$ at lower $\mathrm{pH}$. This effect is more pronounced at lower $\mathrm{pH}$ because the stability of the organic complexes decreases with lower $\mathrm{pH}$. No obvious adsorption effects of FA on the $\mathrm{Hg}$ electrode were observed under these conditions (Murimboh et al. 2000).

Some major cations such as calcium and magnesium affect complexation of $\mathrm{Cd}$ by FA, as shown in Fig. 1. There was an overall decrease in $\mathrm{Cd}$ complexation with increasing Ca concentration due to their competition for the binding sites (Fig. 1). A conditional stability constant of $\mathrm{Ca}-\mathrm{FA} K_{\mathrm{CaFA}}$ can be obtained from our data. The value of $\log K_{\mathrm{CaFA}}$, pH=7.5 was fitted with FITEQL while $\mathrm{CaCO}_{3}$ was treated as one component in the program constraining $\log K_{\mathrm{CdFA}}$, cond to 8.01 and the ligand concentration to $25.6 \mathrm{nmol} / \mathrm{l}$ (Table 1). A conditional binding constant of calcium and FA is then calculated to be $\log K_{\mathrm{CaFA}}$, pH 7.5 $=3.27$. The conditional stability constants listed in Table 1 can be fitted to the following equation as a function of $\mathrm{pH}$ and $\mathrm{Ca}^{2+}$ :

$$
\log K_{\mathrm{CdFA}}=9.11-\log \left(1+10^{3.27}\left[\mathrm{Ca}^{2+}\right]+10^{(7.5-\mathrm{pH})}+10^{(13.5-2 \mathrm{pH})}\right)
$$

Alternatively, a calculation of the Ca competition by WHAM shows a competition effect of similar strength as the measured one, but indicates a systematic difference between modeled and measured data at this $\mathrm{pH}$. This difference may be caused by the difference observed above at lower $\mathrm{pH}$. It may also be due to different characteristics of the used FA and of the standard FA characterized by the WHAM model, and to a different $\mathrm{Cd}$ concentration range than the range in the WHAM calibration (Tipping 1998).

Our results on FA-Cd complexation measured by CLE-SV are similar to those determined previously by the same technique (Xue and Sigg 1999). Some complexing parameters recently published by other techniques, using discrete one-ligand models to express the complexation behavior of humic substances are listed in Table 3. For comparison the $\log K$ obtained from the present study and corrected for the appropriate $\mathrm{pH}$ with Eq. 4 are also listed. Due to the heterogeneous binding sites 
Table 3 Comparison of Cd-FA or Cd-HA complexation measured by CLE-SV and by other techniques

\begin{tabular}{|c|c|c|c|c|c|c|c|}
\hline Sample & $\mathrm{pH}$ & Technique & $\begin{array}{l}\log \\
K_{\text {cond }}\end{array}$ & $\begin{array}{l}\mathrm{L}_{\text {avail }} \\
(\mathrm{mol} / \mathrm{g} \mathrm{C})\end{array}$ & $\begin{array}{l}\log \\
K^{*}\end{array}$ & $\mathrm{Cd}$ titration range & References \\
\hline SRFA & 8.00 & CLE-SV & 9.40 & $4.8 \times 10^{-7}$ & 8.99 & $1.8 \times 10^{-9} \sim 2.9 \times 10^{-8}$ & Xue and Sigg (1999) \\
\hline PPHA & 8.00 & CLE-SV & 8.80 & $3.3 \times 10^{-6}$ & 8.99 & $8.9 \times 10^{-9} \sim 1.8 \times 10^{-8}$ & Xue and Sigg (1999) \\
\hline AHA & 6.00 & DPASV & 6.24 & $8.7 \times 10^{-5}$ & 7.30 & $2 \times 10^{-7} \sim 1.5 \times 10^{-6}$ & Abate and Masini (2002) \\
\hline SRFA & 6.40 & NMR & 3.41 & $7.6 \times 10^{-3}$ & 7.84 & $1 \times 10^{-3} \sim 1 \times 10^{-2}$ & Otto et al. (2001) \\
\hline WRFA & 6.40 & NMR & 3.28 & $6.4 \times 10^{-3}$ & 7.84 & $1 \times 10^{-3} \sim 1 \times 10^{-2}$ & Otto et al. (2001) \\
\hline CLFA & 6.40 & NMR & 3.08 & $6.6 \times 10^{-3}$ & 7.84 & $1 \times 10^{-3} \sim 1 \times 10^{-2}$ & Otto et al. (2001) \\
\hline LSFA & 6.40 & NMR & 3.53 & $3.5 \times 10^{-3}$ & 7.84 & $1 \times 10^{-3} \sim 1 \times 10^{-2}$ & Otto et al. (2001) \\
\hline BBHA & 5.00 & DPASV & 6.18 & $5.2 \times 10^{-5}$ & 5.57 & $2 \times 10^{-7} \sim 1.5 \times 10^{-6}$ & Abate and Masini (2002) \\
\hline BВНА & 6.00 & DPASV & 6.70 & $9.7 \times 10^{-5}$ & 7.30 & $2 \times 10^{-7} \sim 1.5 \times 10^{-6}$ & Abate and Masini (2002) \\
\hline HA comp & 7.00 & ISE & 10.05 & $2.32 \times 10^{-3}$ & 8.46 & $10^{-7} \sim 10^{-4.5}$ & Kaschl et al. (2002) \\
\hline FA comp & 7.00 & ISE & 6.80 & $1.65 \times 10^{-3}$ & 8.46 & $10^{-7} \sim 10^{-4.5}$ & Kaschl et al. (2002) \\
\hline $\mathrm{FA}<1,000$ & 7.00 & ISE & 7.98 & $2.55 \times 10^{-3}$ & 8.46 & $10^{-7} \sim 10^{-4.5}$ & Kaschl et al. (2002) \\
\hline
\end{tabular}

$\log K_{\text {cond }}$ : conditional stability constants

$\log K^{*}$ : conditional stability constant for FA from present study corrected for the corresponding $\mathrm{pH}$ (Eq. 4)

SRFA: Suwannee River fulvic acids

PPHA: purified peat humic acid

AHA: commercial humic acids from Aldrich

WRFA: FA isolated from Wakarusa River, KS

CLFA: FA isolated from Clinton Lake, KS

LSFA: soil fulvic acid isolated from the Laurentian area in Canada

BBHA: sedimentary humic acid isolated from a Brazilian water reservoir

HA comp: humic acid isolated from compost

FA comp: fulvic acid isolated from compost

FA $<1,000$ : fulvic acid after dialysis with a molecular weight cutoff of 1,000 daltons

of fulvic and humic acids, the titration range is also taken into account. If compared using the same techniques, generally stronger complexation by HA is observed than that by FA. Various techniques have been used to determine complexation of Cd by natural organic ligands, each with its own characteristics and limitations. Discrepancy among different studies may be attributed to the different principles of analytical techniques. Using NMR and high $\mathrm{Cd}$ concentrations, weak conditional stability constants are obtained, which probably reflect the effect of the most abundant carboxylate groups on the chemical shift range of ${ }^{113} \mathrm{Cd}$ (Otto et al. 2001). The fitted $\log K$ by NMR are much lower than other measured values, indicating that $\mathrm{Cd}$ may bind to weaker ligand sites at high $\mathrm{Cd}$ concentrations. These results have also been obtained at lower $\mathrm{pH}$. Among the electrochemical determinations, potentiometric measurements with ion selective electrode (ISE) give the highest conditional constants, which compare reasonably with those obtained in the present work. ISE allows a direct determination of the concentration of free ions in solution, but insufficient sensitivity limits its reliable measurement at low $\mathrm{Cd}$ concentrations. A quite large titration range has therefore been used in a study, in which ISE was used (Kaschl et al. 2002). Abate and Masini (2002) obtained similar results for Cd complexation by DPASV measurements as those by CLE-SV, if the lower $\mathrm{pH}$ is taken into account, under conditions in which most of the weaker organic and inorganic complexes would dissociate. The sensitivity of DPASV with a hanging 
mercury electrode is also limited, but is increased with a rotating mercury membrane electrode, as it has been applied successfully in marine water (Bruland 1992). However, ligands, ionic composition, and $\mathrm{pH}$ vary widely in freshwaters, in which the ligands include various natural organic matter such as HA and FA. The CLE-SV technique masks weak organic ligands and improves the sensitivity of DPASV, especially at higher $\mathrm{pH}$.

\subsection{Comparison of Cd complexation with FA and with natural organic ligands from River Wyre and Lake Greifen}

Titration curves of natural organic ligands from River Wyre and Lake Greifen are compared in Fig. 5 with titration curves of FA, using the WHAM model for FA. Input data for the WHAM model are given in Table 4. DOC is assumed to consist of either $100 \%$ FA or $90 \%$ FA $+10 \%$ HA, and FA and HA are assumed to comprise $50 \%$ organic C. Results obtained with these two assumptions are very similar, as also shown in Unsworth et al. (2006). The comparison of the titration curves indicates that the Cd complexation by natural organic ligands from River Wyre is similar to that by FA. The simulated data using WHAM are quite close to the one-ligand fitted curve for the river water. The WHAM simulated curve for FA at the same DOC concentration and $\mathrm{pH}$ is lower than that for Wyre, due to the competition with major metal ions in the input data of the river water (Table 4). In contrast, complexation by natural organic ligands in Lake Greifen is stronger than that by FA and by ligands in River Wyre. The WHAM simulated curve shows much weaker binding than the one-ligand modelling, probably because of stronger ligands, which are not included in the WHAM input. The differences in complexation between the river and the lake may arise from the different character of natural ligands from various sources.

Fig. 5 Comparison of titration curves of FA and DOC from Wyre and Greifen with $\mathrm{Cd}$ in terms of $\log \left[\mathrm{Cd}^{2+}\right]$ versus $\log$ $\left[\mathrm{Cd}_{\text {natural }}\right]$, as calculated by WHAM and by one-ligand model. FA: $I=0.01 \mathrm{M}$; $\left[\mathrm{Ca}^{2+}\right]=1 \mathrm{mM}$, WHAM model with $15 \mathrm{mg} / \mathrm{l}$ of DOC at $\mathrm{pH} 8.0$ or with $5 \mathrm{mg} / \mathrm{l}$ of DOC at $\mathrm{pH}$ 8.5. River Wyre: $\mathrm{pH}=8$, DOC $=15 \mathrm{mg} / \mathrm{l}$, WHAM or one-ligand model; Lake Greifen: $\mathrm{pH}=8.5$; $\mathrm{DOC}=4.85 \mathrm{mg} / \mathrm{l}$, WHAM or one-ligand model

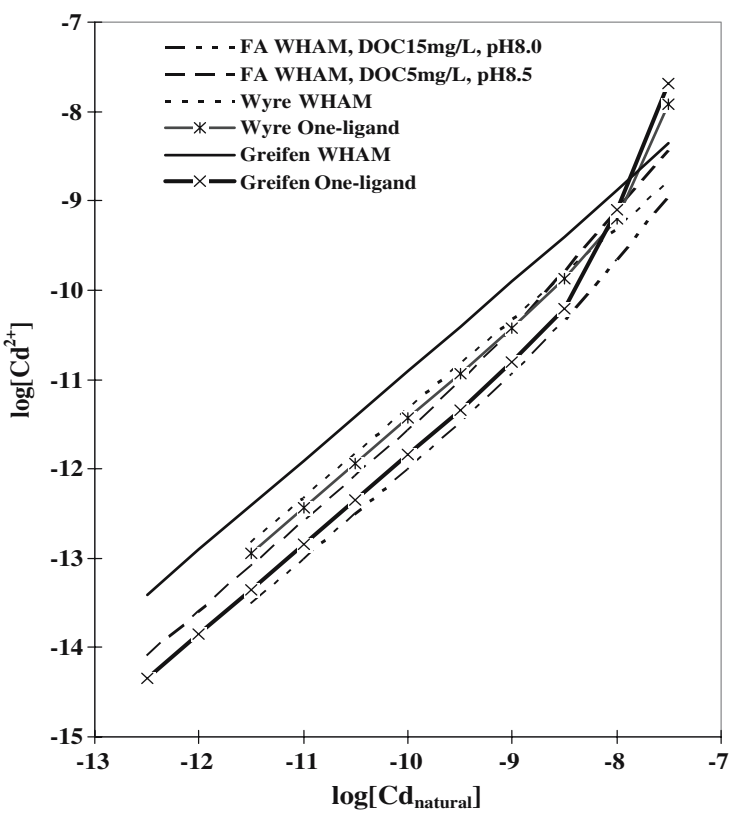


Table 4 WHAM input values for Wyre and Greifen

\begin{tabular}{|c|c|c|c|c|c|c|c|}
\hline & $\mathrm{PH}$ & FA $(g / l)$ & $\mathrm{Fe}_{2} \mathrm{O}_{3}(\mathrm{~g} / \mathrm{l})$ & $\mathrm{Na}(\mathrm{M})$ & $\operatorname{Mg}(\mathrm{M})$ & $\mathrm{Al}(\mathrm{M})$ & \\
\hline Wyre & 8.0 & 0.03 & $4.23 \mathrm{E}-04$ & $3.50 \mathrm{E}-04$ & $1.00 \mathrm{E}-04$ & $3.50 \mathrm{E}-06$ & \\
\hline \multirow[t]{2}{*}{ Greifen } & 8.5 & 0.0097 & - & 4.70E-04 & $6.60 \mathrm{E}-04$ & - & \\
\hline & $\mathrm{K}(\mathrm{M})$ & $\mathrm{Ca}(\mathrm{M})$ & $\mathrm{Cl}(\mathrm{M})$ & $\mathrm{NO}_{3}(\mathrm{M})$ & $\mathrm{SO}_{4}(\mathrm{M})$ & $\mathrm{CO}_{3}(\mathrm{M})$ & \\
\hline Wyre & $4.00 \mathrm{E}-05$ & $4.00 \mathrm{E}-04$ & $2.90 \mathrm{E}-04$ & $6.50 \mathrm{E}-05$ & $8.00 \mathrm{E}-05$ & $7.60 \mathrm{E}-04$ & \\
\hline \multirow[t]{2}{*}{ Greifen } & $9.00 \mathrm{E}-05$ & $7.50 \mathrm{E}-04$ & $5.90 \mathrm{E}-04$ & $9.00 \mathrm{E}-05$ & $2.00 \mathrm{E}-04$ & $2.40 \mathrm{E}-03$ & \\
\hline & $\mathrm{Cd}(\mathrm{M}) *$ & $\mathrm{~Pb}(\mathrm{M})$ & $\operatorname{Mn}(\mathrm{M})$ & $\mathrm{Co}(\mathrm{M})$ & $\mathrm{Ni}(\mathrm{M})$ & $\mathrm{Cu}(\mathrm{M})$ & $\mathrm{Zn}(\mathrm{M})$ \\
\hline Wyre & $\begin{array}{l}3.16 \mathrm{E}-13 \\
3.2 \mathrm{E}-08\end{array}$ & $1.70 \mathrm{E}-09$ & $2.30 \mathrm{E}-07$ & $1.60 \mathrm{E}-09$ & $2.20 \mathrm{E}-08$ & $2.00 \mathrm{E}-08$ & $2.80 \mathrm{E}-08$ \\
\hline Greifen & $\begin{array}{l}3.16 \mathrm{E}-13 \\
3.2 \mathrm{E}-08\end{array}$ & $2.20 \mathrm{E}-10$ & $6.00 \mathrm{E}-09$ & $7.50 \mathrm{E}-10$ & $6.00 \mathrm{E}-09$ & $1.70 \mathrm{E}-08$ & $6.10 \mathrm{E}-09$ \\
\hline
\end{tabular}

*Range of total $\mathrm{Cd}$

Natural organic matter in Lake Greifen may include some freshly produced biological ligands (Xue and Sigg 1999). Although $\mathrm{Ca}$ is higher in Lake Greifen as a competing ion, the natural ligands in the lake still have stronger complexation than those in the river water and than FA. The ligands in River Wyre responsible for Cd complexation may mainly come from humic substances originating from the soils in the catchment area (Unsworth et al. 2006).

Table 5 lists the mean values of $\log K_{\mathrm{CdL}}$, cond and ligand concentration of the ligands from river Wyre, Lake Greifen and FA, respectively. As previously indicated, it is not suitable to use only either the conditional stability constant or the ligand concentration to compare complexation in different samples (Brown et al. 1999; Van Den Berg et al. 1990; Xue and Sigg 2002). Therefore the complexing coefficient $\left(K_{\mathrm{CdL}}\right.$, cond $\left.\times \mathrm{L}_{\text {avail }}\right)$, the Cd titration range and working $\mathrm{pH}$ are also shown in Table 5. Comparing the complexing coefficients, we find that the complexation of ligands from the natural waters, especially for the lake, is stronger than that of FA. The difference may partially originate from the different $\mathrm{pH}$ condition, DOC content and $\mathrm{Cd}$ titration range. For example, while $\mathrm{pH}$ varies 0.5 units, the conditional stability constant of FA might also change by about 0.5 units (Table 1 ). So the differences in $\mathrm{pH}$ limit comparability of the parameters from the two natural waters. Since the sensitivity in determination of sample from Wyre was not satisfying, the detection windows are higher than those from Greifen (Figs. 3 and 4).

No kinetic limitations are expected for the ligand exchange reactions of the ligands detected here. For Cd complexes with $\log K=9-10$ the dissociation rate

Table 5 Comparison of Cd complexation with FA and DOC from Wyre and Greifen

\begin{tabular}{|c|c|c|c|c|c|c|c|c|}
\hline & $\mathrm{pH}$ & & $\log K$ & cond & $\begin{array}{l}\mathrm{L}_{\text {avail }} \\
(\mu \mathrm{mol}\end{array}$ & & $\begin{array}{l}\mathrm{K}_{\mathrm{CdL} \text {, cond }} \\
\times \mathrm{L}_{\text {avail }}\end{array}$ & $\begin{array}{l}\text { Cd titration } \\
\text { range } \mathrm{nmol} / \mathrm{l}\end{array}$ \\
\hline & Mean & Std. & Mean & Std. & Mean & Std. & & \\
\hline Wyre & 8 & - & 9.27 & 0.39 & 1.41 & 0.61 & $2.63 \times 10^{9}$ & $10-120$ \\
\hline Greifen & 8.68 & 0.09 & 9.95 & 0.3 & 3.00 & 2.24 & $2.67 \times 10^{10}$ & $1.72-23.5$ \\
\hline FA & 8 & - & 8.57 & - & 1.67 & - & $6.20 \times 10^{8}$ & $1-50$ \\
\hline & 8.5 & - & 9.07 & - & 1.7 & - & $2.00 \times 10^{9}$ & $5-15$ \\
\hline
\end{tabular}


constants are expected to be in the range $k_{\mathrm{d}}=0.3-3 \times 10^{-3} \mathrm{~s}^{-1}$ (Van Leeuwen and Town 2005). The dissociation of these complexes is thus sufficiently fast over the equilibration time of several hours for ligand exchange.

Within the larger project frame of the present study, several in situ analytical techniques have been simultaneously applied to the softwater river and the hardwater lake (Sigg et al. 2006). Free metal ions may be measured at equilibrium by HFPLM (hollow fiber permeation liquid membranes) when diffusion through the membrane is the rate limiting step, and with DMT (Donnan membrane technique) free metal ions may also be measured at equilibration over a hydrophilic cationexchange membrane. More $\mathrm{Cd}^{2+}$ was measured by HFPLM and DMT than predicted by WHAM VI in Lake Greifen (Unsworth et al. 2006). The result by HFPLM has already been attributed to the appreciable concentrations of $\mathrm{CdCO}_{3}^{0}$ in the lake, which may pass through the membrane and thus increase the total fraction of measured Cd by HFPLM. In contrast, less $\mathrm{Cd}^{2+}$ is found by CLE-SV in this study than by WHAM VI prediction in the lake. This result may be interpreted as indicating stronger ligands in the lake, or alternatively as a low result for $\mathrm{Cd}^{2+}$ due to insufficient equilibration by kinetic limitation, which is not likely as indicated above. In contrast to the in situ techniques, measurements by CLE-SV must be carried out with titrations in the laboratory. Data from CLE-SV only reflect the results at a specific time, and sampling and pretreatment may cause some errors, as we have encountered for the river Wyre samples. To perform further accurate measurements of speciation and free ionic concentration of $\mathrm{Cd}$ in natural waters, further comparison of this method with field measurements using dynamic speciation is needed (Sigg et al. 2006).

Acknowledgements This work was performed within the framework of the BIOSPEC project funded by the European Commission's RTD Programme "Preserving the Ecosystem" (Key Action Sustainable Management and Quality of Water), under contract EVK1-CT-2001-00086. We acknowledge the BIOSPEC group for the sampling and composition determination of the lake and the river, and Frank Black for his determination of $\mathrm{Cd}$ speciation of some lake samples. JC thanks EAWAG for support during her stay.

\section{References}

Abate G, Masini JC (2002) Complexation of $\mathrm{Cd}(\mathrm{II})$ and $\mathrm{Pb}$ (II) with humic acids studied by anodic stripping voltammetry using differential equilibrium functions and discrete site models. Org Geochem 33:1171-1182

Benedetti MF, Milne CJ, Kinniburgh DG, Van Riemsdijk WH, Koopal LK (1995) Metal ion binding to humic substances: application of the non-ideal competitive adsorption model. Environ Sci Technol 29:446-457

Brown GK, Cabaniss SE, MacCarthy P, Leenheer JA (1999) Cu(II) binding by a pH-fractionated fulvic acid. Anal Chim Acta 402:183-193

Bruland KW (1992) Complexation of cadmium by natural organic ligands in the central North Pacific. Limnol Oceanogr 37:1008-1017

Campbell PGC, Errécalde O, Fortin C, Hiriart-Baer VP, Vigneault B (2002) Metal bioavailability to phytoplankton—applicability of the biotic ligand model. Comp Biochem Physiol Part C 133:189_ 206

Gustafsson JP (2001) Modeling the acid-base properties and metal complexation of humic substances with the Stockholm Humic Model. J Colloid Interf Sci 244:102-112

Kaschl A, Romheld V, Chen Y (2002) Cadmium binding by fractions of dissolved organic matter and humic substances from municipal solid waste compost. J Environ Qual 31:1885-1892

Springer 
Kinniburgh DG, Milne CJ, Benedetti MF, Pinheiro JP, Filius J, Koopal LK, Van Riemsdijk WH (1996) Metal ion binding by humic acid: application of the NICA-Donnan model. Environ Sci Technol 30:1687-1698

Kinniburgh DG, van Riemsdijk WH, Koopal LK, Borkovec M, Benedetti MF, Avena MJ (1999) Ion binding to natural organic matter: competition, heterogeneity, stoichiometry and thermodynamic consistency. Colloid Surf A 151:147-166

Kola H, Wilkinson KJ (2005) Cadmium uptake by a green alga can be predicted by equilibrium modelling. Environ Sci Technol 39:3040-3047

Leenheer JA (1989) Structural components and proposed structural models of fulvic acid from the Suwanee River. In: Averett RC, Leenheer JA, McKnight DM, Thron KA (eds.) Humic substances in the Suwanee River, Georgia: interactions, properties and proposed structures, vol 87557. US Geology Survey, pp 331-360

Meylan S, Odzak N, Behra R, Sigg L (2004) Speciation of copper and zinc in natural freshwater: comparison of voltammetric measurements, diffusive gradients in thin films and chemical equilibrium models. Anal Chim Acta 510:91-100

Murimboh J, Lam MT, Hassan NM, Chakrabarti CL (2000) A sudy of Nafion coated and uncoated thin mercury film-rotating disk electrodes for cadmium and lead speciation in model solutions of fulvic acid. Anal Chim Acta 423: 115-126

Otto WH, Carper WR, Larive CK (2001) Measurement of cadmium(II) and calcium(II) complexation by fulvic acids using ${ }^{113}$ Cd NMR. Environ Sci Technol 35:1463-1468

Sigg L, Black F, Buffle J, Cao J, Cleven RFMJ, Davison W, Galceran J, Gunkel P, Kalis EJJ, Kistler D, Martin M, Noel S, Nur Y, Odzak N, Puy J, Van Riemsdijk WH, Temminghoff EJM, TercierWaeber M-L, Toepperwien S, Town RM, Unsworth E, Warnken KW, Weng LP, Xue H, Zhang $\mathrm{H}$ (2006) Comparison of analytical techniques for dynamic trace metal speciation in natural freshwaters. Environ Sci Technol 40:1934-1941

Tipping E (1993) Modeling the competition between alkaline earth cations and trace metal species for binding by humic substances. Environ Sci Technol 27:520-529

Tipping E (1998) Humic ion-binding model VI: an improved description of the interactions of protons and metal ions with humic substances. Aquat Geochem 4:3-48

Tipping E, Hurley MA (1992) A unifying model of cation binding by humic substances. Geochim Cosmochim Acta 56:3627-3641

Toepperwien S (2006) Bioaccumulation of cadmium in Scenedesmus vacuolatus as a function of freshwater parameters. PhD, ETH Zurich. no 16607. $114 \mathrm{pp}$

Unsworth E, Warnken KW, Zhang H, Davison W, Black F, Buffle J, Cao J, Cleven RFMJ, Galceran J, Gunkel P, Kalis EJJ, Kistler D, Van Leeuwen HP, Martin M, Noel S, Nur Y, Odzak N, Puy J, Van Riemsdijk WH, Sigg L, Temminghoff EJM, Tercier-Waeber M-L, Toepperwien S, Town RM, Weng LP, Xue H (2006) Model predictions of metal speciation in freshwaters measured by in situ techniques. Environ Sci Technol 40:1942-1949

Van den Berg CMG, Nimmo M, Daly P, Turner DR (1990) Effects of the detection window on the determination of organic copper speciation in estuarine waters. Anal Chim Acta 232:149-159

Van Leeuwen HP, Town RM (2005) Kinetic limitations in measuring stabilities of metal complexes by competitive ligand exchange-adroptive stripping voltammetry (CLE-AdSV). Environ Sci Technol 39:7217-7225

Van Leeuwen HP, Town RM, Buffle J, Cleven RFMJ, Davison W, Puy J, Van Riemsdijk WH, Sigg L (2005) Dynamic speciation analysis and bioavailability of metals in aquatic systems. Environ Sci Technol 39: 8545-8556

Vigneault B, Campbell PGC (2005) Uptake of cadmium by freshwater green algae: effects of $\mathrm{pH}$ and aquatic humic substances. J Phycol 41:55-61

Westall JC (1982) FITEQL, a program for the determination of chemical equilibrium constants from experimental data. Department of Chemistry, Oregon State University

Xue H, Sigg L (1998) Cd speciation and complexation by natural organic ligands in freshwater. Anal Chim Acta 363:249-259

Xue H, Sigg L (1999) Comparison of the complexation of $\mathrm{Cu}$ and $\mathrm{Cd}$ by humic and fulvic acids and by ligands observed in lake waters. Aquat Geochem 5:313-335

Xue H, Sigg L (2002) A review of competitive ligand-exchange/voltammetric methods for speciation of trace metals in freshwater. In: Rozan TF, Taillefert M (eds.) Environmental electrochemistry: analyses of trace element biogeochemistry, vol 811. AC,Washington, pp 336-370 